NASA/TM-2005-214012

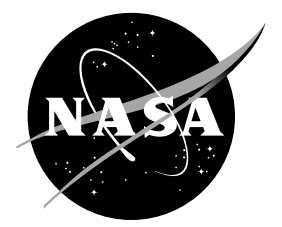

\title{
Magnetic and Electrical Characteristics of Permalloy Thin Tape Bobbin Cores
}

Gene E. Schwarze

Glenn Research Center, Cleveland, Ohio

William R. Wieserman

University of Pittsburgh, Johnstown Campus, Johnstown, Pennsylvania

Janis M. Niedra

QSS Group, Inc., Cleveland, Ohio 
Since its founding, NASA has been dedicated to the advancement of aeronautics and space science. The NASA Scientific and Technical Information (STI) Program Office plays a key part in helping NASA maintain this important role.

The NASA STI Program Office is operated by Langley Research Center, the Lead Center for NASA's scientific and technical information. The NASA STI Program Office provides access to the NASA STI Database, the largest collection of aeronautical and space science STI in the world. The Program Office is also NASA's institutional mechanism for disseminating the results of its research and development activities. These results are published by NASA in the NASA STI Report Series, which includes the following report types:

- $\quad$ TECHNICAL PUBLICATION. Reports of completed research or a major significant phase of research that present the results of NASA programs and include extensive data or theoretical analysis. Includes compilations of significant scientific and technical data and information deemed to be of continuing reference value. NASA's counterpart of peerreviewed formal professional papers but has less stringent limitations on manuscript length and extent of graphic presentations.

- TECHNICAL MEMORANDUM. Scientific and technical findings that are preliminary or of specialized interest, e.g., quick release reports, working papers, and bibliographies that contain minimal annotation. Does not contain extensive analysis.

- CONTRACTOR REPORT. Scientific and technical findings by NASA-sponsored contractors and grantees.
- CONFERENCE PUBLICATION. Collected papers from scientific and technical conferences, symposia, seminars, or other meetings sponsored or cosponsored by NASA.

- SPECIAL PUBLICATION. Scientific, technical, or historical information from NASA programs, projects, and missions, often concerned with subjects having substantial public interest.

- TECHNICAL TRANSLATION. Englishlanguage translations of foreign scientific and technical material pertinent to NASA's mission.

Specialized services that complement the STI Program Office's diverse offerings include creating custom thesauri, building customized databases, organizing and publishing research results ... even providing videos.

For more information about the NASA STI Program Office, see the following:

- Access the NASA STI Program Home Page at http://www.sti.nasa.gov

- E-mail your question via the Internet to help@sti.nasa.gov

- Fax your question to the NASA Access Help Desk at 301-621-0134

- Telephone the NASA Access Help Desk at 301-621-0390

- Write to:

NASA Access Help Desk

NASA Center for AeroSpace Information 7121 Standard Drive

Hanover, MD 21076 
NASA/TM-2005-214012

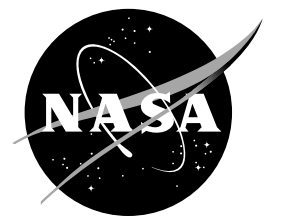

\section{Magnetic and Electrical Characteristics of Permalloy Thin Tape Bobbin Cores}

Gene E. Schwarze

Glenn Research Center, Cleveland, Ohio

William R. Wieserman

University of Pittsburgh, Johnstown Campus, Johnstown, Pennsylvania

Janis M. Niedra

QSS Group, Inc., Cleveland, Ohio

Prepared for the

Second International Energy Conversion Engineering Conference sponsored by the American Institute of Aeronautics and Astronautics Providence, Rhode Island, August 16-19, 2004

National Aeronautics and

Space Administration

Glenn Research Center 


\section{Acknowledgments}

The authors would like to acknowledge the NASA Energetics Project of the Enabling Concepts and Technologies Program for funding this research.

Trade names or manufacturers' names are used in this report for identification only. This usage does not constitute an official endorsement, either expressed or implied, by the National Aeronautics and Space Administration.

Available from

NASA Center for Aerospace Information 7121 Standard Drive

Hanover, MD 21076
National Technical Information Service 5285 Port Royal Road Springfield, VA 22100 


\title{
Magnetic and Electrical Characteristics of Permalloy Thin Tape Bobbin Cores
}

\author{
Gene E. Schwarze \\ National Aeronautics and Space Administration \\ Glenn Research Center \\ Cleveland, Ohio 44135 \\ William R. Wieserman \\ University of Pittsburgh \\ Johnstown Campus \\ Johnstown, Pennsylvania 15904 \\ Janis M. Niedra \\ QSS Group, Inc. \\ Cleveland, Ohio 44135
}

The core loss, that is, the power loss, of a soft ferromagnetic material is a function of the flux density, frequency, temperature, excitation type (voltage or current), excitation waveform (sine, square, etc.) and lamination or tape thickness. In previously published papers we have reported on the specific core loss and dynamic B-H loop results for several polycrystalline, nanocrystalline, and amorphous soft magnetic materials. In this previous research we investigated the effect of flux density, frequency, temperature, and excitation waveform for voltage excitation on the specific core loss and dynamic B-H loop. In this paper, we will report on an experimental study to investigate the effect of tape thicknesses of $1,1 / 2,1 / 4$, and 1/8-mil Permalloy type magnetic materials on the specific core loss. The test cores were fabricated by winding the thin tapes on ceramic bobbin cores. The specific core loss tests were conducted at room temperature and over the frequency range of $10 \mathrm{kHz}$ to $750 \mathrm{kHz}$ using sine wave voltage excitation. The results of this experimental investigation will be presented primarily in graphical form to show the effect of tape thickness, frequency, and magnetic flux density on the specific core loss. Also, the experimental results when applied to power transformer design will be briefly discussed.

\section{Introduction}

The core loss, that is, the power loss, of a soft ferromagnetic material is a function of the magnetic flux density, excitation frequency, temperature, type of excitation, (voltage or current), excitation waveform (sine, square, etc.), and lamination or tape thickness. In previously published papers $[1,2,3,4,5,6]$ we have reported on the specific core loss and dynamic B-H hysteresis loops for several polycrystalline, nanocrystalline and amorphous soft magnetic materials. In this previous research we investigated the effect of flux density, frequency, temperature, and excitation waveform for voltage excitation on the specific core loss and dynamic B-H hysteresis loop. The soft magnetic materials investigated included an $80 \mathrm{Ni}$-Fe crystalline alloy [1, 2,5], two 50Ni-Fe crystalline alloys [3], a $2 \mathrm{~V}-49 \mathrm{Fe}-49 \mathrm{Co}$ crystalline alloy [4], a grain oriented $3 \mathrm{Si}-\mathrm{Fe}$ crystalline alloy [4], two iron-based amorphous alloys $[1,2,3]$, two cobalt-based amorphous alloys [6], and an iron-based nanocrystalline alloy [6].

Magnetic component designers are always searching for new or improved soft magnetic materials to increase the efficiency and power density of transformers, motors, and generators, and the energy density of inductors. The primary means to increase the power density is to increase the operating frequency [7]. But increasing the operating frequency without decreasing the magnetic flux density, will in general, increase the core loss, and thus, decrease the component's efficiency. So in most instances the trade-off between power density and efficiency comes down to a trade between operating frequency and magnetic flux density for a given core material of given lamination thickness and operating temperature.

In this paper we will report the effect of tape thickness of bobbin wound cores on the specific core loss and the $\mathrm{DC}$ and $\mathrm{AC}$ coercive force. The specific core loss (SCL) is the core loss per unit mass or volume. The coercive force is the H-field where the magnetic flux density is zero on the B-H hysteresis loop. When the magnetic flux density becomes saturated, the coercive force is then known as the coercivity. The coercive force is a measure of 
the core loss. An increase in the coercive force will cause an increase in the core loss. The magnetic materials investigated are generally known in the trade as Permalloy. The thicknesses of the tapes were: 1-mil, 1/2-mil, $1 / 4 \mathrm{mil}$, and 1/8-mil, where 1 -mil $=10^{-3} \mathrm{inch}=25.4 \mu \mathrm{m}$.

\section{Core Loss Theory}

The magnetic and electrical properties of ferromagnetic materials include saturation magnetization, Curie temperature, permeability, remanence, coercivity, core loss, and in general, the size and shape of the B-H hysteresis loop. These properties are dependent on material composition, impurities present, mechanical strains introduced during processing, heat treatments, magnetic anneals, crystal structure and crystal orientation. The amount of irreversible energy expended during cyclic magnetization of a ferromagnetic material is called the core or power loss and makes its presence known through the generation of heat in the material. The B-H hysteresis loop area is a graphical representation of the heat generated within the material.

The classical or conventional approach to core loss, postulated prior to the introduction of domain theory, separates the core loss into hysteresis and eddy current loss components. A third component, the anomalous loss, was introduced when the apparent eddy current loss exceeded the classical eddy current loss. The area of so called DC or static B-H hysteresis loop is proportional to the hysteresis loss which is defined as the energy (heat) expended in a ferromagnetic material as a result of magnetic irreversibility (hysteresis) when the magnetic flux density is cyclic.

The eddy current loss is the energy (heat) expended by the circulating currents induced through the time variation of the magnetic flux in the core laminations or the convolutions of spirally wound tape cores. Various approaches are used to derive the classical eddy current loss equation and the details of one such approach are given in reference 8 in which the following equation is derived:

$$
\mathrm{P}_{\mathrm{ec}}=\mathrm{KB}_{\mathrm{m}}{ }^{2} \mathrm{f}^{2} \mathrm{~d}^{2} \mathrm{~V} / \mathrm{\rho}
$$

where:

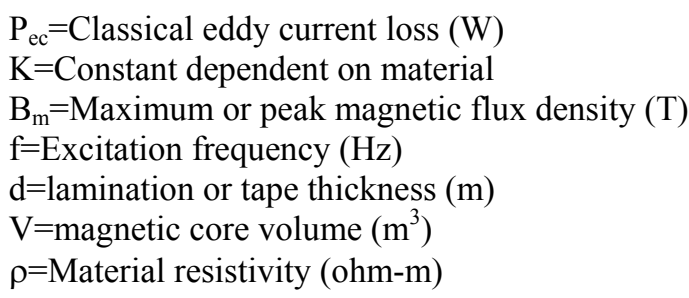

From Equation (1) it is readily seen that a $2 \mathrm{x}$ reduction in tape thickness should cause a $4 \mathrm{x}$ reduction in the classical eddy current loss. However, it should be remarked that for thin ferromagnetic materials, their domain structure may cause the eddy current loss to deviate from the above $\mathrm{d}^{2}$ rule. As $\mathrm{d}$ decreases, the large-scale ("global") eddy currents, to which Equation (1) applies, become less significant as compared to the eddy currents circulating locally about the domain walls. The latter might be expected, at first, to give a contribution proportional to $\mathrm{d}$ to the eddy current losses, and finally, change to some other dependence as the domain structure itself changes due to the increasing influence of surface domains.

The primary focus of this paper will be to investigate how the total core loss varies as a function of tape thickness for a given flux density and frequency. The validity of the tape thickness squared term in the classical eddy current loss given by Equation 1 will be then investigated. The effect of frequency on the total core loss for a given magnetic flux density and tape thickness will also be investigated and compared to the classical $\mathrm{f}^{2}$ dependence.

\section{Material and Test Core Description}

The magnetic core material used in this experimental investigation was a Nickel(Ni)-Iron(Fe)-Molybdenum(Mo) alloy of nominal chemical composition of $79 \% \mathrm{Ni}, 19 \% \mathrm{Fe}$ and $4 \% \mathrm{Mo}$ by weight [10]. In the soft magnetic materials community, this nominal composition is referred to by various names. For example, Magnetics, A Division of Spang, fabricates Round Permalloy 80, Square Permalloy 80, and Supermalloy tape wound cores while Arnold Engineering Company fabricates 4-79 Permalloy, Square Permalloy, and Supermalloy tape wound cores. The difference in the magnetic and electrical properties of the "Permalloy" type of magnetic materials is determined by the impurities present, trace elements added, and the heat treatment and magnetic anneals used in processing the material to its final thickness. For example, Magnetics' literature [9] gives the following for a typical 2-mil thick 
tape wound core: For Supermalloy a saturation flux density of $0.65 \mathrm{~T}$ to $0.82 \mathrm{~T}$ and a DC coercive force of 0.003 Oe to 0.008 Oe; for Square Permalloy 80 , a saturation flux density of $0.66 \mathrm{~T}$ to $0.82 \mathrm{~T}$ and a DC coercive force of 0.02 Oe to 0.04 Oe.

The thin tape wound core materials used in this investigation were fabricated by Magnetics. The 1-mil, 1/2-mil, and 1/4-mil thick tape material was Supermalloy but the 1/8-mil thick tape material was Square Permalloy 80 . The initial objective was to use Supermalloy for all of the thin tapes. During the fabrication of the cores, Magnetics informed us that they were unable to fabricate 1/8-mil thick Supermalloy tape but could provide this thickness in Square Permalloy 80 . The reason given was that difficulties were encountered during the rolling process of the $1 / 8$-mil thick tape. The details on why $1 / 8$-mil Supermalloy could not be produced were not conveyed to us. We recognized that, in a sense, we would have two different materials if the Square Permalloy 1/8-mil thick tapes were used, and as a consequence, could not make a true comparison of the core loss as a function of tape thickness from 1-mil to 1/8-mil. However, for completeness it was decided that the $1 / 8$-mil thick material should be included in the investigation to see how its core loss characteristics compared with the other three tape thicknesses. In the experimental results discussion, it will be seen that the core loss behavior of the $1 / 8$-mil thick material does deviate from the core loss trend of the other 3 tape thicknesses.

The test cores were wound by Magnetics using ceramic bobbin cores of approximately O.D. $=1.375$ in., I.D. $=0.875$ in., and wall thickness $=0.0625$ in. Sufficient tape was wound on the bobbin to make a layer $1 / 8$ " thick to give the magnetic core dimensions of O.D. $=1.25 \mathrm{in}$., I.D. $=1.00 \mathrm{in}$. and width $=0.250 \mathrm{in}$. These magnetic core dimensions are the same as the dimensions of the toroidal wound cores tested in our previous investigations $[1,2,3,4,5,6]$. The bobbins were used because the thin tapes needed to be structurally supported during the winding and anneal process. The bobbin was made from ceramic to allow future investigation of these core materials at elevated temperatures to $300^{\circ} \mathrm{C}$.

\section{Experiment Description}

The measurement system used to measure, compute, plot, and display the electrical and magnetic characteristics of the test core material is shown in Figure 1. A key element in the measurement system is the power amplifier used to excite the core material. The introduction of amplitude distortion by the amplifier will produce erroneous core loss and B-H loops. The means to obtain the specific core loss (SCL) and dynamic B-H loops from the primary exciting current, $\mathrm{i}_{\mathrm{p}}(\mathrm{t})$, and the secondary induced voltage, $\mathrm{e}_{\mathrm{s}}(\mathrm{t})$, waveforms is described and discussed in reference 1 .

Room temperature data for a single core for the 1,1/2,1/4, and 1/8-mil thick tape test cores were taken over the frequency range of 10 to $750 \mathrm{kHz}$. A sinusoidal voltage applied to the primary winding provided the excitation of the core material. The resultant primary current and secondary induced voltage waveforms were obtained for frequencies of $10,50,100,300,500$, and $750 \mathrm{kHz}$. The maximum flux density was either the saturation flux density of $0.7 \mathrm{~T}$ at $10 \mathrm{kHz}$ or that flux density for which the SCL remained less than $100 \mathrm{~W} / \mathrm{lb}$. Particular attention was paid to prevent local heating of the test core by capturing the required waveforms in the minimum length of time.

\section{Experimental Results and Discussion}

A considerable amount of test data was taken for the 1,1/2, and 1/4-mil thick tape Supermalloy and 1/8-mil thick tape Square Permalloy 80 to characterize the core loss and dynamic B-H loops of these materials. The effect of the maximum flux density (Bm), frequency (f), and tape thickness (d) on the specific core loss (SCL) can best be seen and analyzed for trends by plotting the data as follows:

1. $\quad \mathrm{SCL}$ vs $\mathrm{B}_{\mathrm{m}}$ with $\mathrm{f}$ as parameter and fixed $\mathrm{d}$.

2. $\mathrm{SCL}$ vs $\mathrm{f}$ with $\mathrm{B}_{\mathrm{m}}$ as parameter and fixed $\mathrm{d}$.

3. $\mathrm{SCL}$ vs $\mathrm{d}$ with $\mathrm{f}$ as parameter and fixed $\mathrm{B}_{\mathrm{m}}$.

4. $\mathrm{SCL} v \mathrm{vs}$ with $\mathrm{d}$ as parameter and fixed $\mathrm{B}_{\mathrm{m}}$.

All of the data plotted in the figures to follow were taken at room temperature using a sine wave voltage to excite the core material. Representative plots of the SCL vs. $\mathrm{B}_{\mathrm{m}}$ over the frequency range of 10 to $750 \mathrm{kHz}$ for the Supermalloy 1/4-mil thick tape and the Square Permalloy 80, 1/8-mil thick tape are given in Figures $2 \mathrm{a}$ and $2 \mathrm{~b}$, respectively. The curves in these plots show that for a given $\mathrm{f}$, the SCL tends to increase almost linearly with $\mathrm{B}_{\mathrm{m}}$ $(0.01 \mathrm{~T}-1 \mathrm{~T})$ on a $\log -\log$ scale, and for a given $\mathrm{B}_{\mathrm{m}}$, the SCL increases with increasing $\mathrm{f}$. The plots in Figures $3 \mathrm{a}$ and $3 \mathrm{~b}$ show how the SCL increases nearly linearly on a log-log scale over the Bm range of $0.03 \mathrm{~T}$ to $0.5 \mathrm{~T}$. It should be 
noted that similar trends were found for the 1 and 1/2-mil thick tape Supermalloy cores as for the Supermalloy 1/4-mil thick tape core for SCL vs $B_{m}$ with $f$ as the parameter and also for SCL vs $f$ with $B_{m}$ as the parameter.

The data most pertinent to the stated objective of this paper are plotted in Figures $4 \mathrm{a}$ and $4 \mathrm{~b}$. Figure $4 \mathrm{a}$ plots the SCL as a function of tape thickness for $\mathrm{B}_{\mathrm{m}}=0.3 \mathrm{~T}$ and frequencies 10,50 , and $100 \mathrm{kHz}$. Figure $4 \mathrm{~b}$ is similar to Figure $4 \mathrm{a}$ except here $\mathrm{B}_{\mathrm{m}}=0.1 \mathrm{~T}$ and includes the additional frequencies of 300 and $500 \mathrm{kHz}$. The most noticeable observation in both of these figures is that for each of the frequencies shown, the SCL decreases as the tape thickness decreases from 1 to 1/4-mil and then increases for the 1/8-mil material. As previously discussed, the 1, $1 / 2$, and 1/4-mil thick tapes were made from Supermalloy material and the 1/8-mil thick tape was made from Square Permalloy 80 material. To note this change in type of material, a dashed line is used in Figures $4 \mathrm{a}$ and $4 \mathrm{~b}$ between the tape thickness of $1 / 4$ and $1 / 8$-mil.

No definitive conclusion can be reached as to whether this increase in SCL for the 1/8-mil thick tape is due to the change in material or whether it is due to rolling the material too thin and forming a structure which increases the number of pinning sites for the domain walls to hang up on. Most likely this increase in total loss is due to the hysteresis loss component and not the eddy current loss component but additional experimentation would be required to confirm this conjecture. From a physicist's viewpoint, the increase in SCL for the 1/8-mil thick tape material compared to the 1/4-mil thick tape is of interest, because knowing what causes this increase could give insight as to the core loss mechanisms involved when the material is rolled to a very thin layer. From an engineer's viewpoint, it is of little interest what causes the losses to be greater for the 1/8-mil thick tape than for the 1/4-mil thick tape, because the magnetic component designer would choose the 1/4-mil thick tape to get the lowest SCL regardless of how the magnetic material's vendor designates and labels their material.

The data in Figures $4 \mathrm{a}$ and $4 \mathrm{~b}$ can be used to determine the change in the SCL as the tape thickness decreases. Using the $100 \mathrm{kHz}$ data in Figure 4b, it is found that the SCL is reduced by a factor of 2.2 and 1.6 by going from the 1 to $1 / 2$ to $1 / 4$-mil thick tape. If it is assumed that this reduction in SCL is due only to a reduction in eddy current loss, then according to Equation 1, a 2x reduction in tape thickness should give a 4x reduction in eddy current loss. As is obvious, there is a significant difference between the experimental and theoretical classical eddy current loss expression. From the experimental results, it should also be noted that the decrease in SCL is less from the 1 to $1 / 2$ mil than it is from the $1 / 2$ to $1 / 4$-mil thick tape. This finding indicates that the rate of reduction in SCL diminishes as the tape thickness decreases.

The data in Figures $4 \mathrm{a}$ and $4 \mathrm{~b}$ can also be used to determine the change in the SCL as the frequency increases. Using the Supermalloy 1/4-mil thick tape data in Figure 4b, it is found that the SCL increases by a factor of 27 for a $10 \mathrm{x}$ change in frequency from 10 to $100 \mathrm{kHz}$ and a factor of 33 from 50 to $500 \mathrm{kHz}$. Again, if we assume that this increase is due only to eddy current loss, then according to Equation 1, a 10x increase in frequency should give a $100 \mathrm{x}$ increase in eddy current loss. Again, there is a significant difference between the experimental SCL data and the theoretical classical eddy current loss expression.

The experimental results in Figures $4 \mathrm{a}$ and $4 \mathrm{~b}$ would strongly indicate that the frequency and tape thickness squared terms in the classical eddy current loss expression do not give the correct physical interpretation of the mechanisms involved in generating the eddy current loss. For, as shown above, by decreasing the tape thickness from 1 to 1/4-mil, the SCL decreases significantly less than that predicted by the classical eddy current loss expression. Also, by increasing the frequency, the SCL increases significantly less than that predicted by Equation 1.

Another very interesting way to show the effect of tape thickness and frequency on the SCL is to plot SCL as a function of the frequency with the tape thickness as the parameter and $\mathrm{Bm}$ fixed. Figure $5 \mathrm{a}$ is for $\mathrm{B}_{\mathrm{m}}=0.1 \mathrm{~T}$ and Figure $5 \mathrm{~b}$ is for $\mathrm{B}_{\mathrm{m}}=0.03 \mathrm{~T}$. Both plots readily show that the Supermalloy 1-mil thick tape has the highest SCL and the 1/4-mil Supermalloy tape has the lowest SCL for the frequency range of $10 \mathrm{kHz}$ to $750 \mathrm{kHz}$. However, as both plots show, the SCL for the 1/8-mil Square Permalloy 80 material is higher than the SCL for the Supermalloy 1-mil thick tape at $10 \mathrm{kHz}$ until the frequency reaches $33.8 \mathrm{kHz}$ for $\mathrm{B}_{\mathrm{m}}=0.1 \mathrm{~T}$ and $26.12 \mathrm{kHz}$ for $\mathrm{B}_{\mathrm{m}}=0.03 \mathrm{~T}$. At these frequencies the SCL of the 1/8-mil thick tape becomes less than that for the 1-mil thick tape. The SCL of the 1/8mil thick tape continues to decrease relative to the 1-mil SCL until the frequency reaches $300 \mathrm{kHz}$ for $\mathrm{B}_{\mathrm{m}}=0.1 \mathrm{~T}$ and $205 \mathrm{kHz}$ for $\mathrm{B}_{\mathrm{m}}=0.03 \mathrm{~T}$. At these frequencies the SCL curve of the 1/8-mil thick tape crosses the SCL curve for the 1/2-mil thick tape. This trend of the SCL of the 1/8-mil thick tape occurring at higher frequencies as $\mathrm{B}_{\mathrm{m}}$ increases would indicate that for higher $\mathrm{B}_{\mathrm{m}}$, the 1/8-mil thick tape SCL curve will never cross the 1/2-mil thick tape SCL curve, and possibly it will never cross the 1-mil thick tape SCL curve. 


\section{Summary and Conclusion}

An experimental study was conducted to investigate the effect of tape thickness of Permalloy type magnetic materials on the specific core loss and dynamic B-H hysteresis loops. Prior experimental studies $[1,2,3,4,5,6]$ conducted on various types of polycrystalline, nanocrystalline, and amorphous soft magnetic materials investigated the effect of maximum flux density, frequency, and temperature on the specific core loss and dynamic B-H loops. The present experimental study of very thin tapes of Permalloy type material wound on bobbin cores and tested over the frequency range of $10 \mathrm{kHz}$ to $750 \mathrm{kHz}$, showed that the specific core loss at room temperature decreased as the tape thickness decreased from 1 to 1/4-mil, but increased as the tape thickness decreased from 1/4 to 1/8-mil. The decrease in specific core loss between the 1/2 and 1/4-mil thick tapes was less than between the 1 and 1/2-mil tapes. The decrease in the experimental core loss as a function of tape thickness for a given frequency and maximum flux density for Supermalloy was considerably less than that predicted by the classical eddy current loss expression. The experimental results also showed that the 1/8-mil thick tape Square Permalloy 80 material had higher specific core loss than the Supermalloy 1/4-mil thick tape material.

The experimental results obtained also made it possible to investigate the effect of frequency on the specific core loss for these very thin Permalloy tapes. This frequency investigation showed that the specific core loss increased with frequency for a given maximum flux density and tape thickness but the increase was significantly less than that predicted by the classical eddy current loss expression.

From the magnetic component designer's viewpoint, the best material to use from this investigation would be the Supermalloy 1/4-mil thick tape material because it gave the lowest losses over the frequency range of $10 \mathrm{kHz}$ to 750 kHz. By using the Supermalloy 1/4-mil thick tape material at high frequencies in, for example, a power transformer, the size of the transformer's core would decrease and as a result, the transformer's power density (7) would increase but at the expense of the transformer's efficiency, because the higher frequency would give higher specific core loss.

\section{References}

${ }^{1}$ Weiserman, W.R., Schwarze, G.E., and Niedra, J.M., "High Frequency, High Temperature Specific Core Loss and Dynamic B-H Hysteresis Loop Characteristics of Soft Magnetic Alloys," $25^{\text {th }}$ Intersociety Energy Conversion Engineering Conference, Reno, Nevada, August 12-17, 1990.

${ }^{2}$ Weiserman, W.R., Schwarze, G.E., and Niedra, J.M, "Comparison of High Frequency, High Temperature Core Loss and B-H Loop Characteristics of an 80 Ni-Fe Crystalline Alloy and Two Iron-Based Amorphous Alloys," Eighth Symposium on Space Nuclear Power Systems Proceedings, Part Three, Albuquerque, N.M., January 6-10, 1991.

${ }^{3}$ Weiserman, W.R., Schwarze, G.E., and Niedra, J.M, "Comparison of High Temperature, High Frequency Core Loss and Dynamic B-H Loops of Two 50 Ni-Fe Crystalline Alloys and an Iron-Based Amorphous Alloy," $26^{\text {th }}$ Intersociety Energy Conversion Engineering Conference Proceedings, Boston, MA, August 4-9, 1991.

${ }^{4}$ Weiserman, W.R., Schwarze, G.E., and Niedra, J.M, "Comparison of High Temperature, High Frequency Core Loss and Dynamic B-H Loops of a 2V-49Fe-49Co and a Grain Oriented 3Si-Fe Alloy," 27 $7^{\text {th }}$ Intersociety Energy Conversion Engineering Conference, San Diego, CA, August 3-7, 1992.

${ }^{5}$ Schwarze, G.E., Weiserman, W.R., and Niedra, J.M, "Effects of Temperature, Frequency, Flux Density and Excitation Waveform on the Core Loss and Dynamic B-H Loops of Supermalloy," 30th Intersociety Energy Conversion Engineering Conference, Orlando, FL, July 31-August 4, 1995.

${ }^{6}$ Niedra, J.M., Schwarze, G.E., "Wide Temperature Core Loss Characteristics of Transverse Magnetically Annealed Amorphous Tapes for High Frequency Aerospace Magnetics," 34th Intersociety Energy Conversion Engineering Conference, Vancouver, British Columbia, Canada, August 1-5, 1999.

${ }^{7}$ Schwarze, G.E., "Development of High Frequency Low Weight Power Magnetics for Aerospace Power Systems," Nineteenth Intersociety Energy Conversion Engineering Conference, San Francisco, CA, August 19-24, 1984.

${ }^{8}$ Barranger, John, "Hysteresis and Eddy-Current Losses of a Transformer Lamination Viewed as an Application of the Pointing Theorem," NASA TN D-3114, November, 1965.

${ }^{9}$ Magnetics, Tape Wound Cores Design Manual, TWC-500, 1998. 


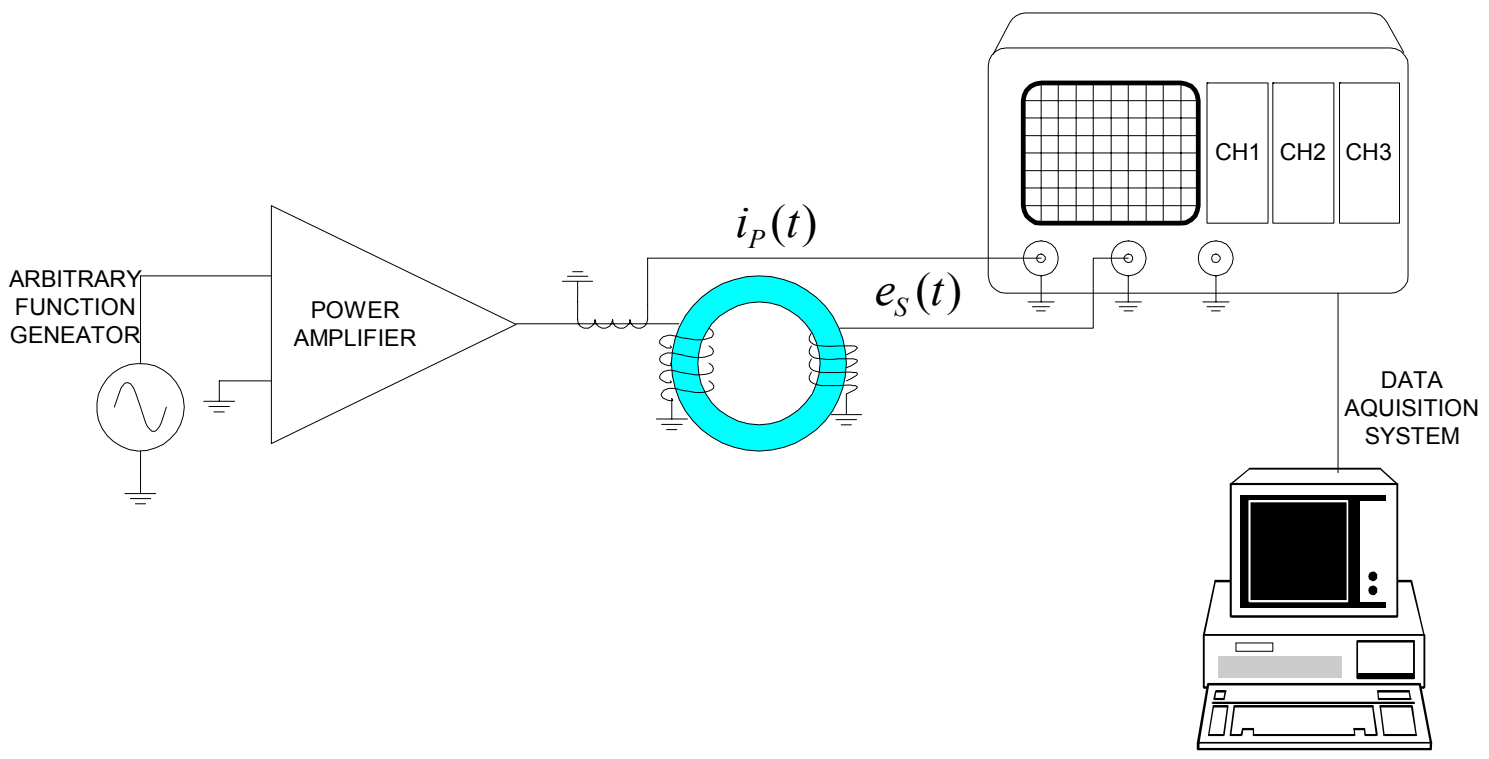

Figure 1.-Specific core loss and dynamic B-H hysteresis loop measurement system. 


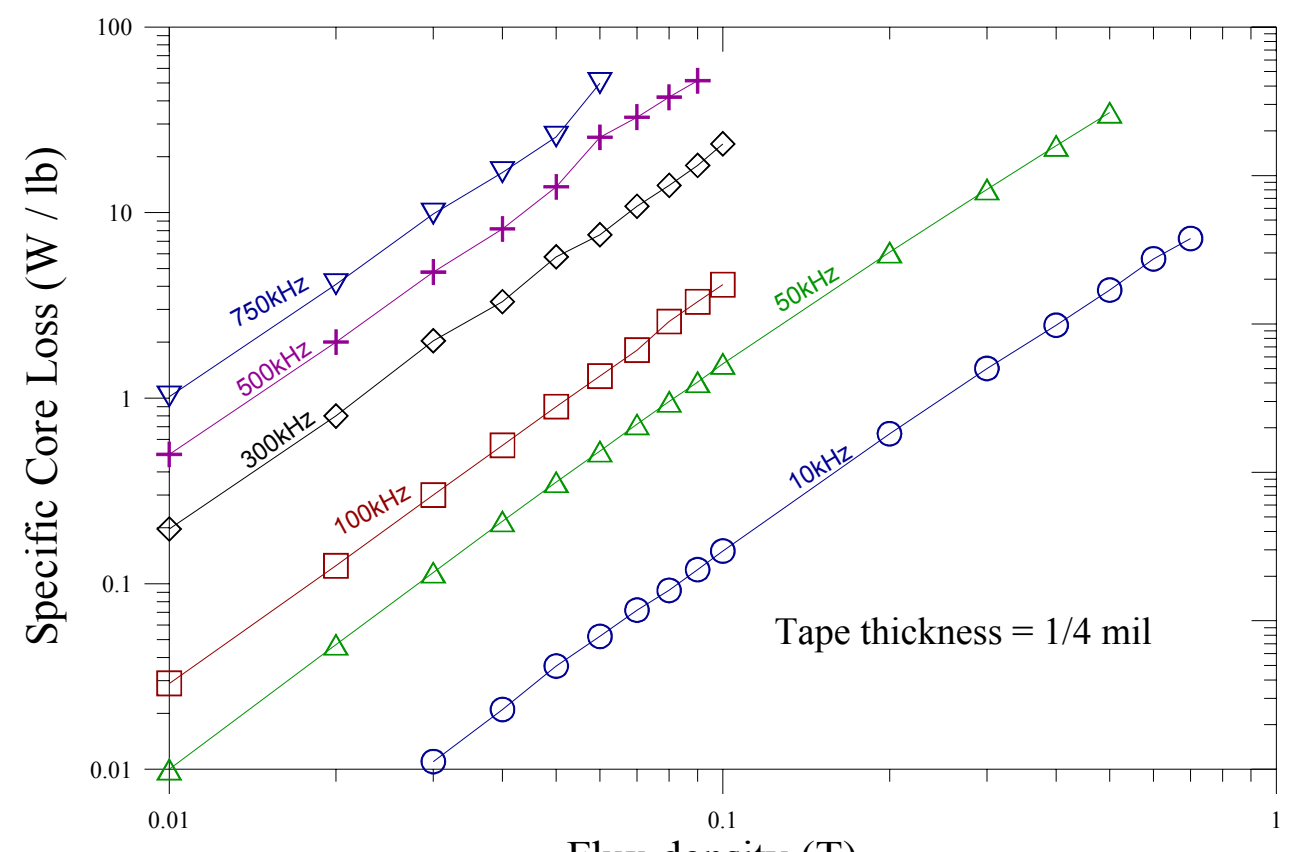

Flux density (T)

(a)

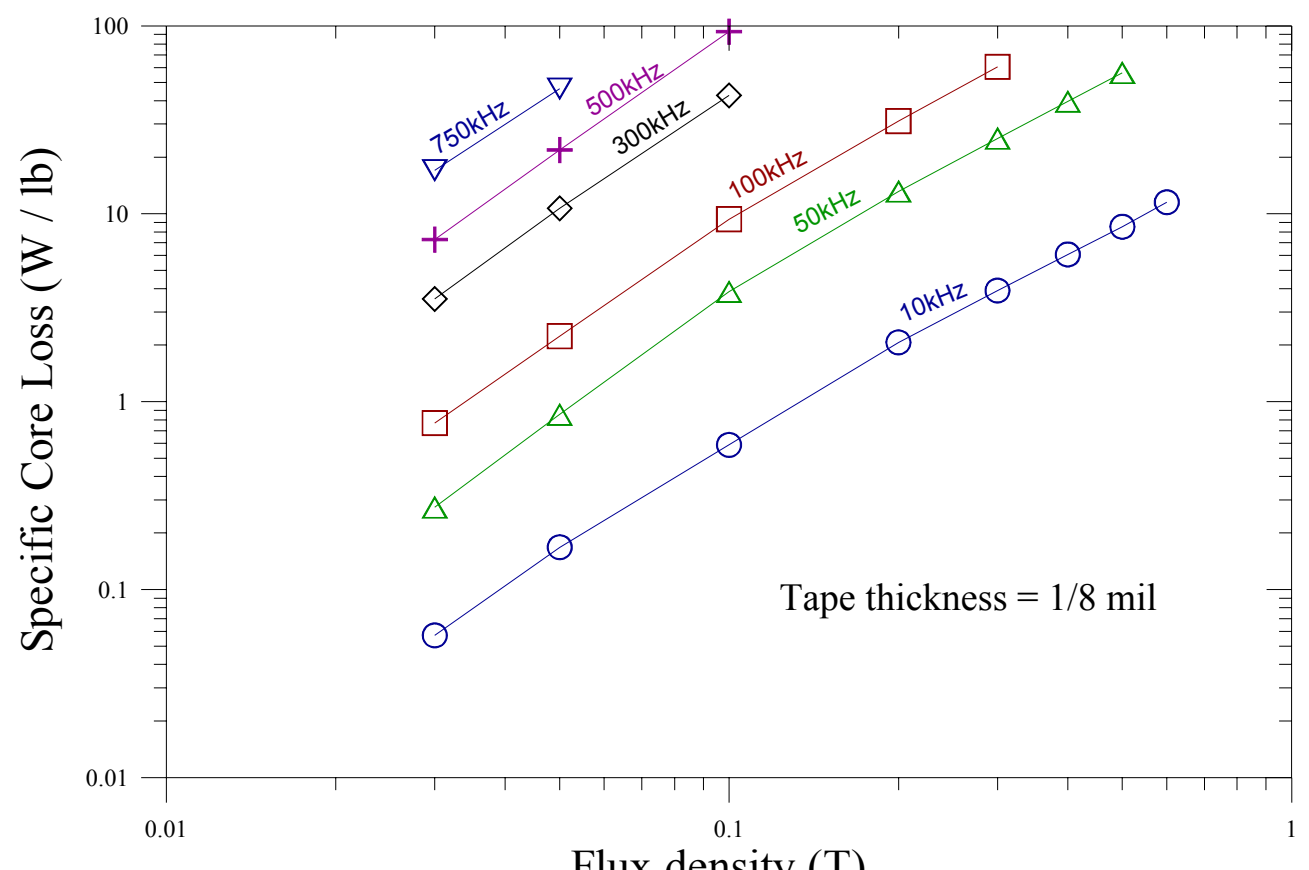

Flux density (T)

(b)

Figure 2.- Room temperature specific core loss for sinewave voltage excitation versus maximum flux density for various frequencies. (a) Supermalloy 1/4-mil thick tape, (b) Square Permalloy 80, 1/8-mil thick tape. 


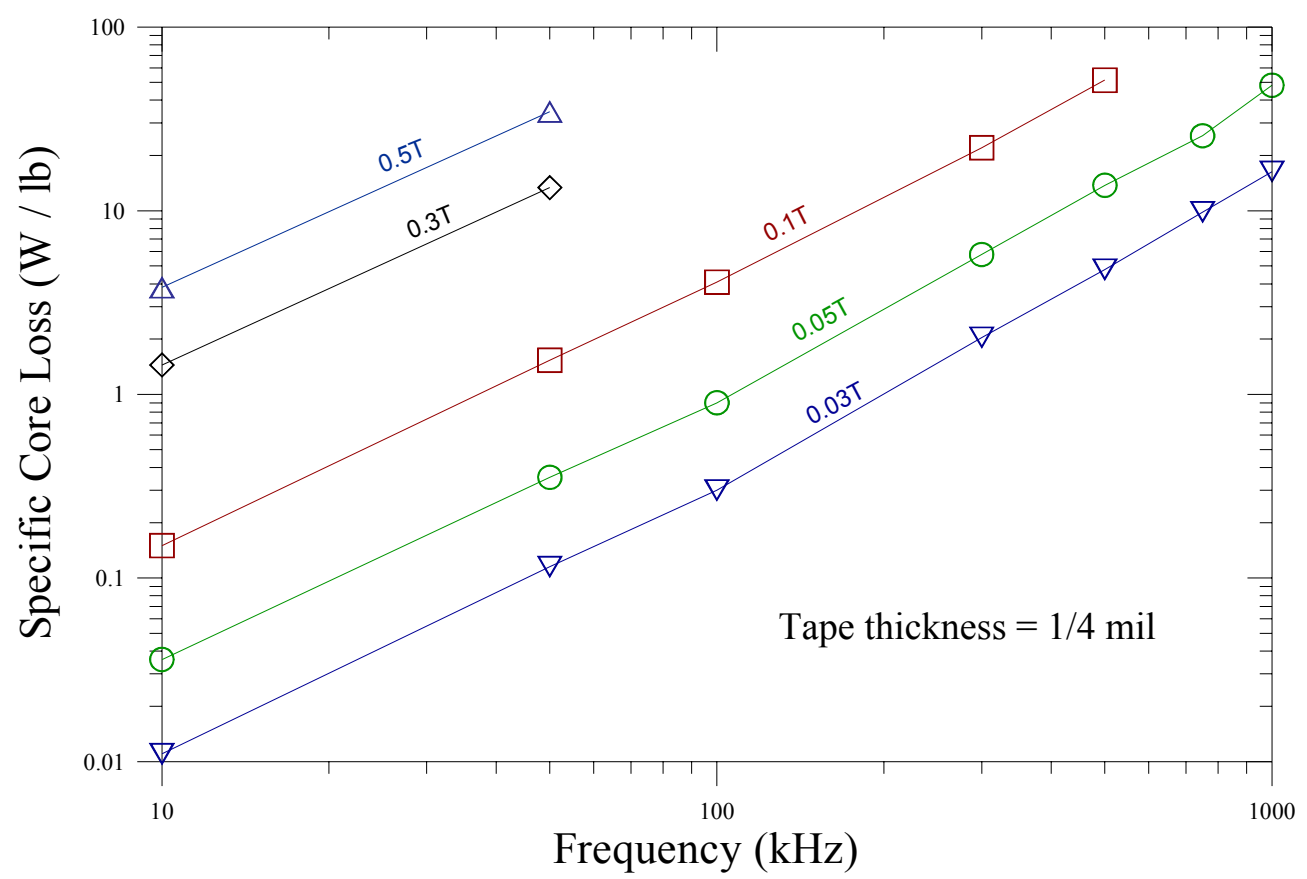

(a)

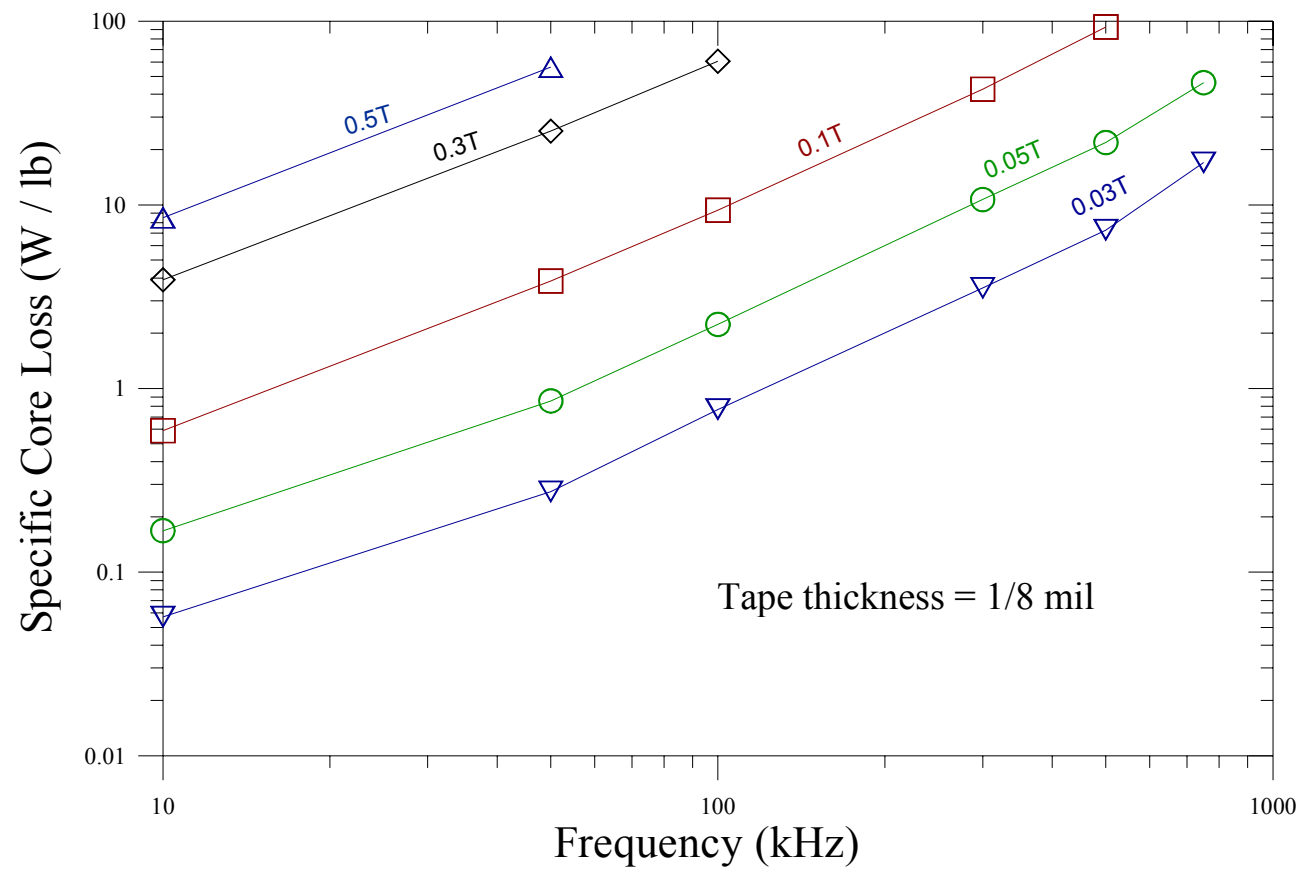

(b)

Figure 3.-Room temperature specific core loss for sinewave voltage excitation versus frequency for various maximum flux densities. (a) Supermalloy 1/4-mil thick tape, (b) Square Permalloy 80, 1/8-mil thick tape. 


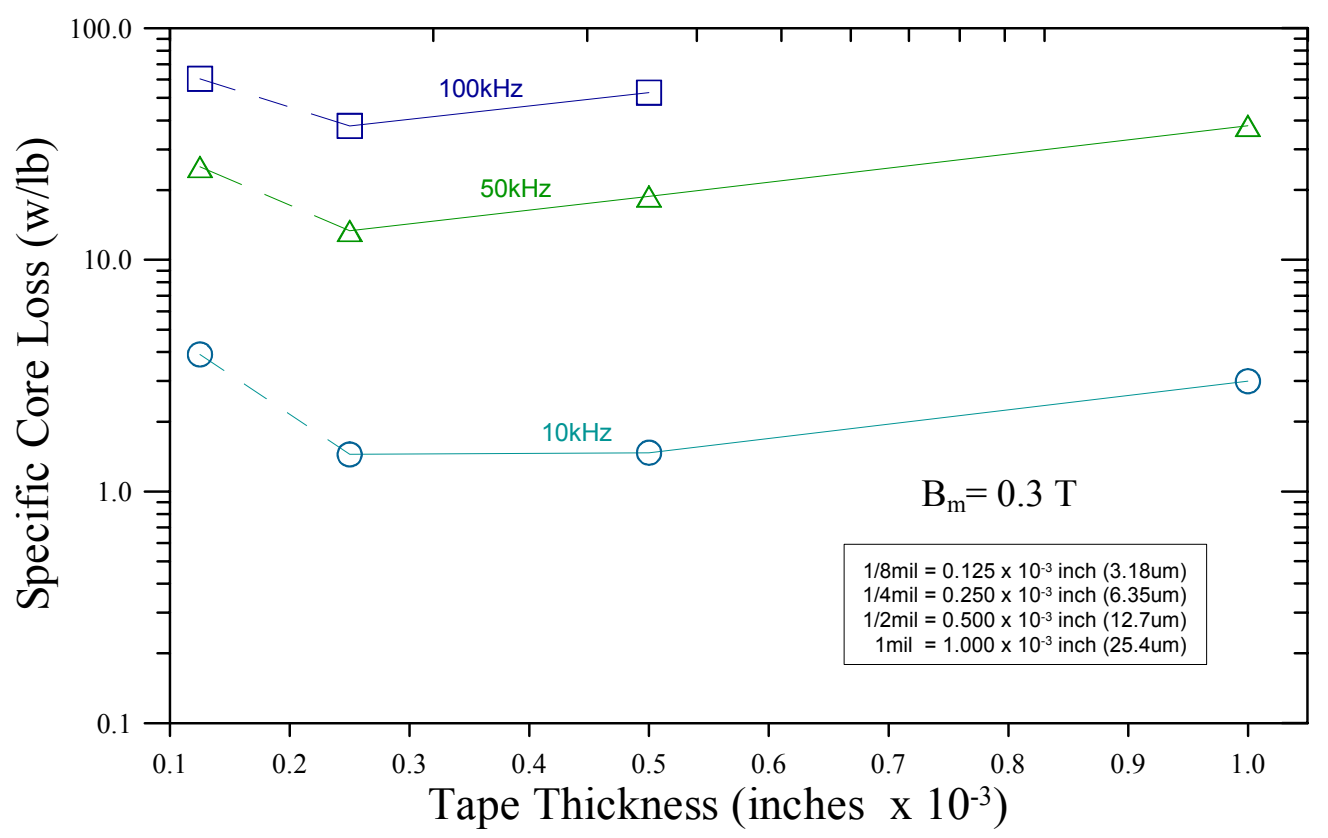

(a)

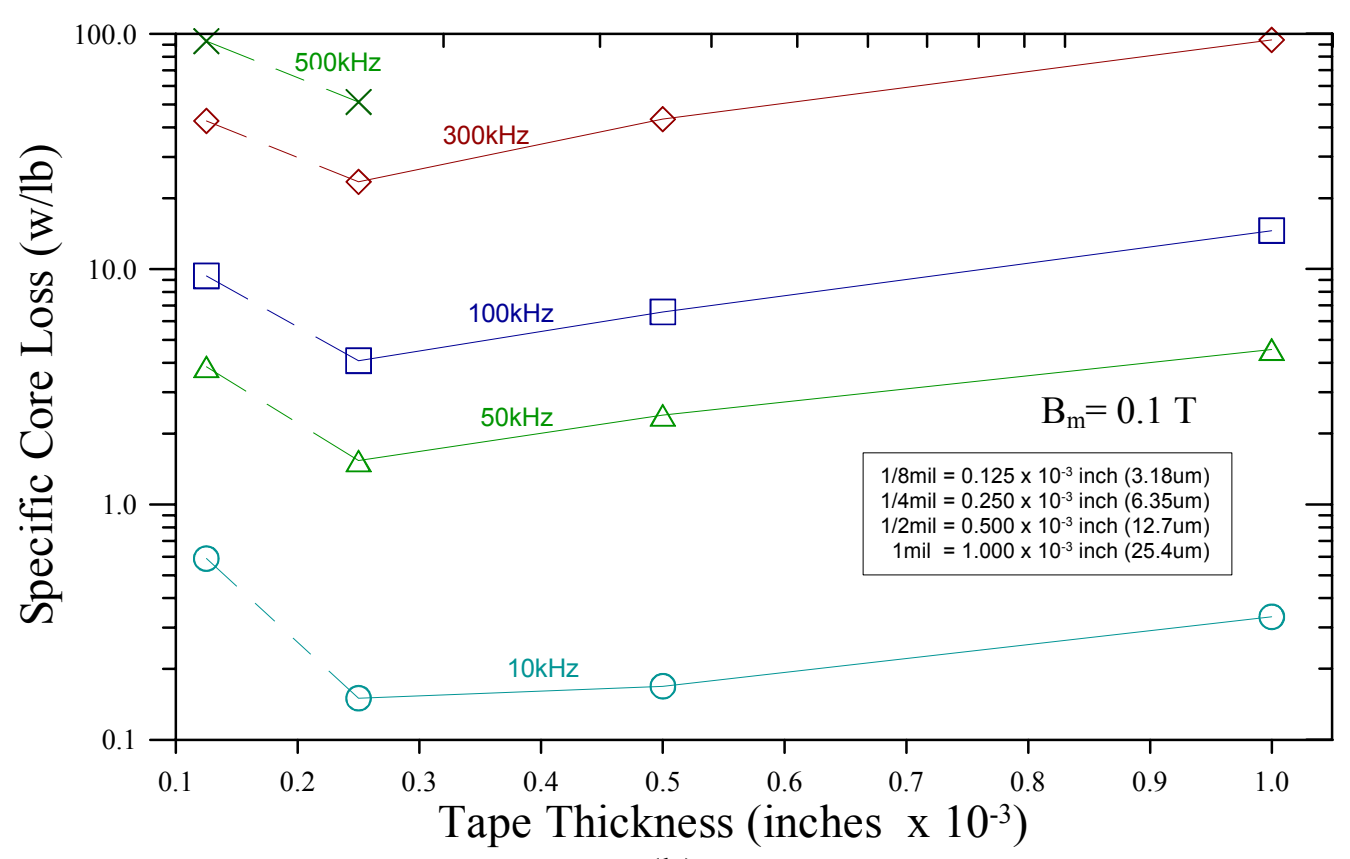

(b)

Figure 4.- - Room temperature specific core loss for sinewave voltage excitation versus tape thickness for various frequencies. Solid line is for Supermalloy and dashed line is for Square Permalloy 80. (a) $B_{m}=0.3 \mathrm{~T}$, (b) $\mathrm{B}_{\mathrm{m}}=0.1 \mathrm{~T}$. 


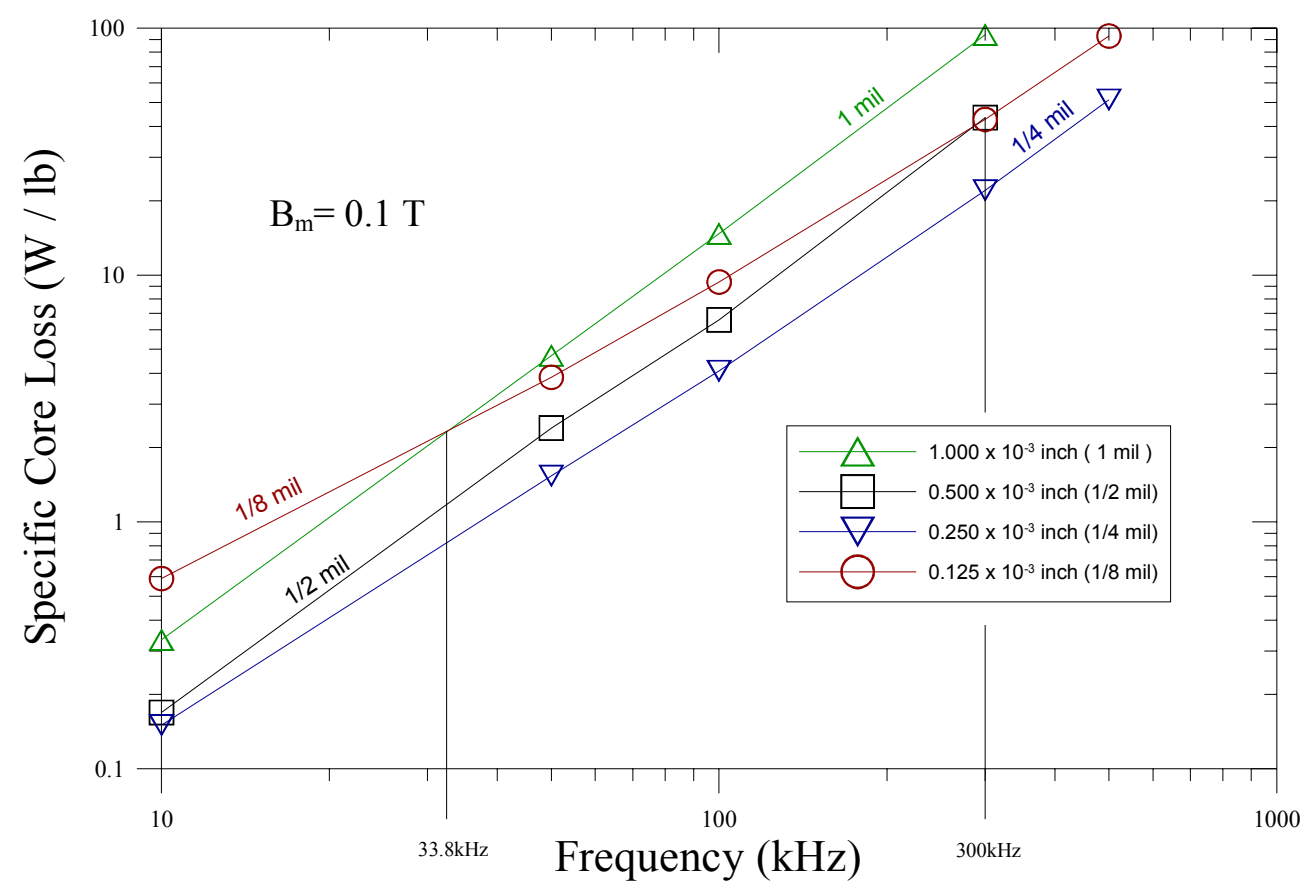

(a)

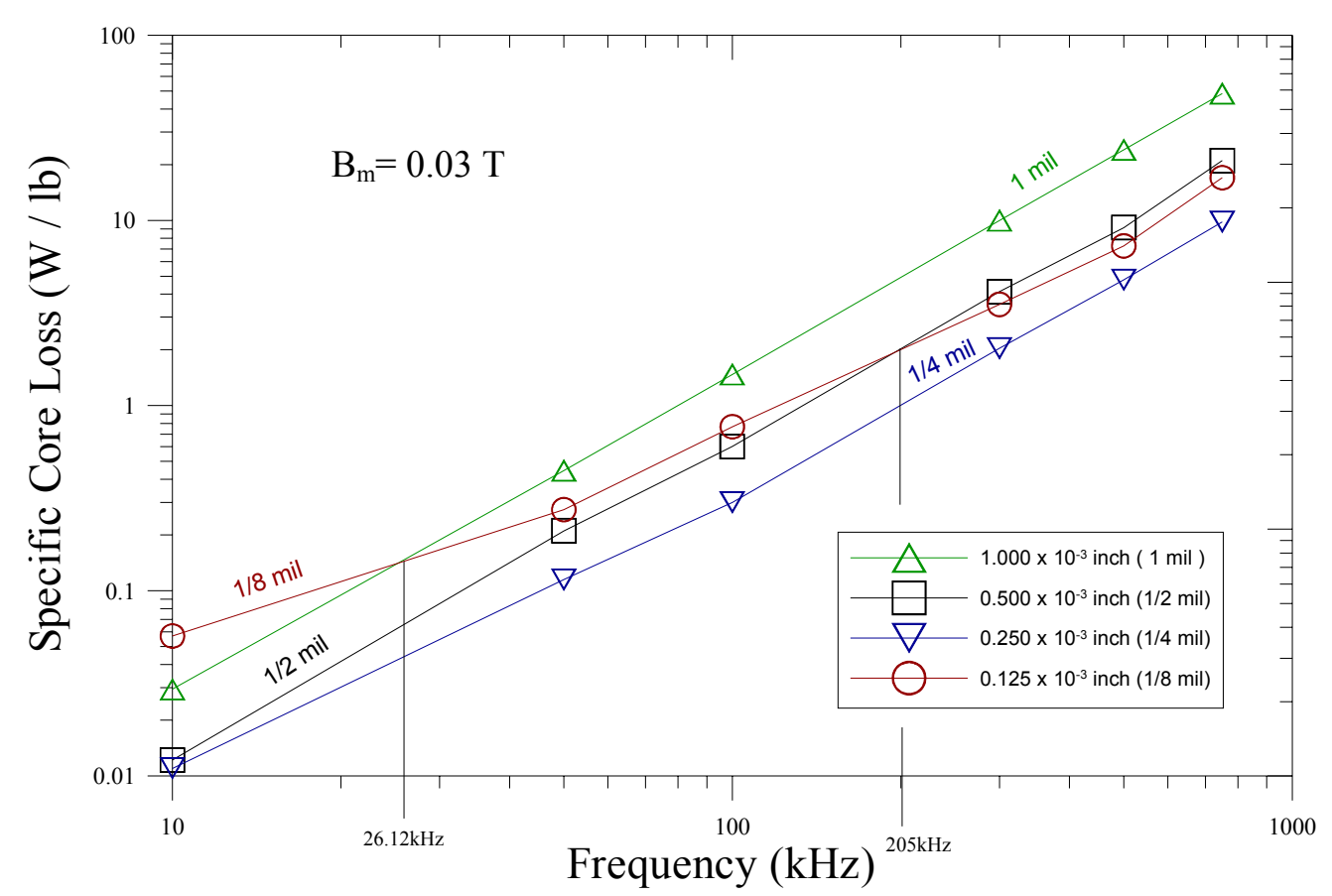

(b)

Figure 5.- Room temperature specific core loss for sinewave voltage excitation versus frequency for various tape thicknesses. The 1,1/2 and 1/4 -mil thick tapes are Supermalloy and the 1/8-mil thick tape is Square Permalloy 80. (a) $\mathrm{B}_{\mathrm{m}}=0.1 \mathrm{~T}$, (b) $\mathrm{B}_{\mathrm{m}}=0.03 \mathrm{~T}$. 
Public reporting burden for this collection of information is estimated to average 1 hour per response, including the time for reviewing instructions, searching existing data sources, gathering and maintaining the data needed, and completing and reviewing the collection of information. Send comments regarding this burden estimate or any other aspect of this
collection of information, including suggestions for reducing this burden, to Washington Headquarters Services, Directorate for Information Operations and Reports, 1215 Jefferson Davis Highway, Suite 1204, Arlington, VA 22202-4302, and to the Office of Management and Budget, Paperwork Reduction Project (0704-0188), Washington, DC 20503.

\begin{tabular}{|l|l|l} 
1. AGENCY USE ONLY (Leave blank) & $\begin{array}{c}\text { 2. REPORT DATE } \\
\text { December } 2005\end{array}$ & $\begin{array}{r}\text { 3. REPORT TYPE AND DATES COVERED } \\
\text { Technical Memorandum }\end{array}$
\end{tabular}

4. TITLE AND SUBTITLE 5. FUNDING NUMBERS

Magnetic and Electrical Characteristics of Permalloy Thin Tape Bobbin Cores

6. AUTHOR(S)

WBS-22-319-20-N1

Gene E. Schwarze, William R. Wieserman, and Janis M. Niedra

7. PERFORMING ORGANIZATION NAME(S) AND ADDRESS(ES)

National Aeronautics and Space Administration

John H. Glenn Research Center at Lewis Field

Cleveland, Ohio 44135-3191

8. PERFORMING ORGANIZATION REPORT NUMBER

E-15330

9. SPONSORING/MONITORING AGENCY NAME(S) AND ADDRESS(ES)

National Aeronautics and Space Administration

Washington, DC 20546-0001

10. SPONSORING/MONITORING AGENCY REPORT NUMBER

NASA TM-2005-214012

AIAA-2004-5749

11. SUPPLEMENTARY NOTES

Prepared for the Second International Energy Conversion Engineering Conference sponsored by the American Institute of Aeronautics and Astronautics, Providence, Rhode Island, August 16-19, 2004. Gene E. Schwarze, NASA Glenn Research Center; William R. Wieserman, University of Pittsburgh, Johnstown Campus, 450 Schoolhouse Road, Johnstown, Pennsylvania 15904; and Janis M. Niedra, QSS Group, Inc., 21000 Brookpark Road, Cleveland, Ohio 44135. Responsible person, Gene E. Schwarze, organization code RPE, 216-433-6117.

12a. DISTRIBUTION/AVAILABILITY STATEMENT

12b. DISTRIBUTION CODE

Unclassified - Unlimited

Subject Category: 33

Available electronically at http://gltrs.grc.nasa.gov

This publication is available from the NASA Center for AeroSpace Information, 301-621-0390.

13. ABSTRACT (Maximum 200 words)

The core loss, that is, the power loss, of a soft ferromagnetic material is a function of the flux density, frequency, temperature, excitation type (voltage or current), excitation waveform (sine, square, etc.) and lamination or tape thickness. In previously published papers we have reported on the specific core loss and dynamic B-H loop results for several polycrystalline, nanocrystalline, and amorphous soft magnetic materials. In this previous research we investigated the effect of flux density, frequency, temperature, and excitation waveform for voltage excitation on the specific core loss and dynamic B-H loop. In this paper, we will report on an experimental study to investigate the effect of tape thicknesses of 1-, 1/2-, 1/4-, and 1/8-mil Permalloy type magnetic materials on the specific core loss. The test cores were fabricated by winding the thin tapes on ceramic bobbin cores. The specific core loss tests were conducted at room temperature and over the frequency range of 10 to $750 \mathrm{kHz}$ using sine wave voltage excitation. The results of this experimental investigation will be presented primarily in graphical form to show the effect of tape thickness, frequency, and magnetic flux density on the specific core loss. Also, the experimental results when applied to power transformer design will be briefly discussed.

14. SUBJECT TERMS

Specific core loss; B-H hysteresis loop; Permalloy; High frequency; Magnetic measurements; Transformers; Magnetic cores

\begin{tabular}{|c|c|c|}
\hline $\begin{array}{c}\text { 17. SECURITY CLASSIFICATION } \\
\text { OF REPORT } \\
\text { Unclassified }\end{array}$ & $\begin{array}{c}\text { 18. SECURITY CLASSIFICATION } \\
\text { OF THIS PAGE } \\
\text { Unclassified }\end{array}$ & $\begin{array}{c}\text { 19. SECURITY CLASSIFICATION } \\
\text { OF ABSTRACT } \\
\text { Unclassified }\end{array}$ \\
\hline
\end{tabular}



